\title{
Isolasi Zat Warna Alami Dari Labu Kuning (Cucurbita Maschata) Dan Penerapannya Untuk Pewarna Makanan
}

\section{Isolation of Natural Dye from Pumpkin (Cucurbita Maschata) and Its Application for Food Coloring}

\author{
Luthfi Amanati \\ Balai Riset dan Standardisasi Industri Surabaya \\ Kementerian Perindustrian \\ Surabaya, Indonesia \\ Lutphie_a@yahoo.com
}

\author{
Sukmawati \\ Balai Riset dan Standardisasi Industri Surabaya \\ Kementerian Perindustrian \\ Surabaya, Indonesia \\ baristandsurabaya@yahoo.com
}

\begin{abstract}
Abstrak- Tujuan dari penelitian ini adalah untuk mengekstraksi zat warna karotenoid ( zat warna alami ) dari labu kuning (Cucurbita moschata) dan penerapanya untuk pewarna makanandengan menggunakan pelarut Ethyl Asetat. Ekstrak zat warna yang diperoleh diamati karakteristiknya terhadap pengaruh lama pemanasan, suhu pemanasan, suhu penyimpanan, lama penyimpanan pada suhu dingin selama 5 hari dan penerapannya untuk pewarna sirup. Hasilnya menunjukkan bahwa zat warna hasil ekstraksi dengan menggunakan pelarut ethyl asetat mempunyai absorbansi maksimum 0,5059 dan rendemen $2,353 \%$.Karakterisasi zat warna hasil ekstraksi : Pengaruh lama pemanasan pada suhu 100 oC selama 1 jam absorbansinya 0,355 , pemanasan pada suhu 100 oC selama 2 jam absorbansinya 0,283 , Pengaruh penyimpanan pada suhu 30 oC selama 1 jam absorbansinya 0,378 , penyimpanan pada suhu 30o $\mathrm{C}$ selama 2 jam absorbansinya 0,346. Sedang penyimpanan pada lemari es selama 5 hari, hari pertama penyimpanan absorbansinya 0,3112 , sdang pada hari kelima penyimpanan absorbansiny turun menjadi 0,2264. Penggunaan zat warna hasil ekstraksi pada sirup secara visual menunjukkan warna kuning cerah pada penyimpanan pada suhu kamar dan pada suhu dingin ( lemari es )
\end{abstract}

\section{Kata Kunci - karatenoid; labu kuning}

Abstract-The purpose of this study was to extract the dye carotenoids (natural pigments) of pumpkin (Cucurbita moschata) and their applicability to dye makanandengan using Ethyl Acetate solvent. Extracts obtained dye was observed characteristics to the effects of prolonged heating, the heating temperature, storage temperature, storage duration at cold temperature for 5 days and its application to dye syrup. The results showed that the dye extraction using ethyl acetate solvent has a maximum absorbance of 0.5059 and the yield of $2.353 \%$.Caracterization dye extraction results: Effects of prolonged heating at 100 for 1 hour $^{\circ} \mathrm{C}$ an absorbance of 0.355 , heating at a temperature of $100^{\circ} C$ for 2 hours an absorbance of 0.283 , Effect of storage at $30^{\circ}$ for 1 hour ${ }^{\circ} \mathrm{C}$ an absorbance of 0.378 , storage at $30^{\circ} C$ for 2 hours an absorbance of 0.346. Average storage in the refrigerator for 5 days, the first day of storage an absorbance of 0.3112 , on the fifth day of storage sdang absorbansiny fell to 0.2264. The use of dye extraction in syrup visually indicates bright yellow color on storage at room temperature and at cold temperatures (freezer)

Keywords_caratenoid; pumpkin

\section{PENDAHULUAN}

Adanya larangan pemerintah tentang penggunaan zat pewarna sintetik yang berbahaya tetapi banyak jajanan anak yang menggunakan pewarna sintesis berbahaya beredar karena itu perlu adanya penelitian untuk mencari sumber zat warna alami yang dapat digunakan untuk zat pewarna makanan yang aman bagi masyarakat. Labu Kuning (Cucurbita maschata) merupakan tanaman dengan hasil produksi melimpah, kandungan gizi lengkap, mudah didapat sebagai pewarna, tahan lama, merupakan jenis tanaman sayuran, tetapi dapat dimanfaatkan untuk berbagai jenis makanan, seperti: roti, dodol, kolak, manisan dan sebagainya. Penelitian ini bertujuan untuk mengekstraksi zat warna karotenoid ( zat warna alami ) dari labu kuning (Cucurbita moschata) dan penerapanya untuk pewarna makanan dan hanya dibatasi dalam memilih bahan baku yang digunakan pewarna makanan yaitu dengan menggunakan labu yang berwarna kuning karena dapat menunjang industri hilir, menyediakan produk makanan minuman. (Labu kuning lebih disukai konsumen karena disamping rasanya lebih enak, kaya akan zat gizi ).

\section{TINJAUAN PUSTAKA}

Labu kuning memiliki kandungan gizi yang cukup lengkap yaitu karbohidrat, protein, dan vitamin. Karena kandungan gizinya yang cukup lengkap ini, labu kuning dapat menjadi sumber gizi yang sangat potensial dan harganya pun terjangkau oleh masyarakat yang membutuhkannya.

Banyak bahan pangan lokal Indonesia yang mempunyai potensi gizi dan komponen bioaktif yang baik, namun belum 
dimanfaatkan secara optimal. Banyak bahan pangan lokal Indonesia yang mempunyai potensi gizi dan komponen bioaktif yang baik, namun belum dimanfaatkan secara optimal. Banyaknya pedagang makanan dan minuman menggunakan pewarna berbahaya Adanya larangan pemerintah tentang penggunaan zat pewarna yang berbahaya Besarnya biaya produksi jika menggunakan pewarna food grade pewarna makanan yang diperbolehkan. Maka perlu adanya penelitian untuk mencari sumber zat warna alami yang dapat digunakan untuk zat pewarna makanan yang aman bagi masyarakat Labu kuning (cucurbita maschata) kaya akan, pro vitamin A kalsium,fosfor, besi, karbohidrat dan protein.

Warna kuning cerah labu mengandung salah satu pigmen karotenoid diantaranya $\beta$ karoten.Labu kuning mengandung karotenoid yang tinggi mencapai 160 mg/100 gr.pigmen warna kuning, merah dan oranye. berfungsi sebagai prekursor vitamin A dan antioksidan. dapat dikeluarkan melalui cara ekstraksi.Ekstrak zat warna yang di hasilkan dapat di aplikasikan ke beberapa jenis makanan dan minuman. Warna yang dihasilkan terhadap jenis makanan dan minuman tidak jauh beda dengan warna yang dihasilkan jika menggunakan warna sintetis.Kandungan Gizi Labu Kuning Labu kuning juga dikenal kaya akan karotenoid yang berfungsi sebagai antioksi dan beta karoten merupakan salah satu jenis karotenoid, disamping mempunyai aktivitas biologis sebagai provitamin-A, juga dapat berperan sebagai antioksidan yang efektif pada konsentrasi oksigen rendah. Kandungan beta karoten pada labu kuning sebesar $1,18 \mathrm{mg} / 10 \mathrm{~g}$. Manfaat lain labu kuning adalah mengobati demam, migrain, diare, penyakit ginjal, serta membantu menyembuhkan radang. Kandungan gizi dari buah labu kuning seperti Tabel 1. [1]

TABLE I. KANDUNGAN GIZI BUAH LABU KUNING

\begin{tabular}{|l|c|}
\hline \multicolumn{1}{|c|}{ Kandungan Gizi } & Jumlah \\
\hline Energi ( kal ) & 32 \\
\hline Protein ( gram ) & 1,1 \\
\hline Lemak ( gram ) & 0,1 \\
\hline Karbohidrat ( gram ) & 6,6 \\
\hline Kalsium ( milligram ) & 45 \\
\hline Fosfor (milligram ) & 64 \\
\hline Besi (milligram ) & 1,4 \\
\hline Karoten total $(\mu \mathrm{g})$ & 180 \\
\hline Tiamin (mg) & 0,08 \\
\hline Air (gram) & 91,2 \\
\hline Vitamin C (milgram) & 52 \\
\hline
\end{tabular}

Karotenoid sebagai provitamin A mempunyai sifat fisik dan kimia larut dalam lemak, larut dalam Kloroform, Benzene, Karbondisulfida, dan Petroleum Eter, tetapi sukar larut di dalam alkohol, serta sensitf terhadap oksidasi,autoksidasi dan sinar. Berikut ini merupakan sifat-sifat dari beta karoten [2]:

- Rumus molekul : C40H16

- Bobot molekul : 536,87 g mol-1
- Density : 0,941 $\pm 0,06 \mathrm{~g} / \mathrm{cm} 3$

- Bentuk : kristal prisma heksagonal dan berwarna ungu tua dari kristalisasi pelarut benzene dan metanol, berbentuk plat kuadratik dan berwarna merah dari kristalisasi dalam pelarut petroleum eter.

- Titik leleh : $181-182^{\circ} \mathrm{C}$

- Optik aktif : beta karoten mempunyai struktur yang simetris dan bersifat non optik aktif.

- Kromatografi : beta karoten sangat kuat diserap oleh kalsium hidroksida dalam larutan petroleum eter. Didalam kolom kromatografi $\beta$-karoten dibawah $\gamma$-karoten dan diatas $\alpha$ - karoten. Dengan posisi tersebut beta karoten sangat sulit diserap oleh zeng karbonat ( $\mathrm{ZnCO} 3)$ dan kalsium karbonat (CaCO3).

- Oksidasi : diudara bebas karoten mengikat oksigen dan menaikan kecepatan pembentukan warna yang lebih pucat. Autoksidasi beta15 karoten murni dimulai setelah beberapa hari kontak dengan udara dan akan terbentuk formaldehid.

Pencampuran beta karoten dalam karbon tetraklorida dengan oksigen menghasilkan sedikit glioksal. [3], menyatakan bahwa degradasi karoten yang terjadi selama pengolahan diakibatkan oleh proses oksidasi pada suhu tingi yang mengubah senyawa karoten menjadi senyawa ionon berupa keton. Senyawa karotenoid mudah teroksidasi terutama pada suhu tinggi yang disebabkan oleh adanya sejumlah ikatan rangkap dalam struktur molekulnya. Banyak faktor yang dapat mempengaruhi kestabilan karoten. [4], menyebutkan bahwa karoten stabil pada $\mathrm{pH}$ netral, alkali namun tidak stabil pada kondisi asam, adanya udara atau oksigen, cahaya dan panas.

Karotenoid tidak stabil karena mudah teroksidasi oleh adanya oksigen dan peroksida. Selain itu, dapat mengalami isomerisasi bila terkena panas, cahaya dan asam. Isomerisasi dapat menyebabkan penurunan intensitas warna .Faktor Yang Berpengaruh Terhadap Menurunya Kandungan Beta Karoten Beta karoten merupakan pro-vitamin A yang sangat mudah rusak akibat pengaruh lingkungan sekitar. Proses pemasakan yang tepat tidak akan mengurangi kandungan beta karoten di dalam makanan.

Kadar beta karoten daging buah labu kuning segar adalah $19,9 \mathrm{mg} / 100 \mathrm{~g}$. Kandungan gizinya yang cukup lengkap ini, maka labu kuning dapat menjadi sumber gizi yang sangat potensial dan harganya pun terjangkau sehingga bisa dikembangkan sebagai alternatif pangan masyarakat. [5]

Bahan pewarna secara sederhana dapat didefinisikan sebagai suatu benda berwarna yang memiliki afinitas kimia terhadap benda yang diwarnainya.Bahan pewarna pada umumnya memiliki bentuk cair dan larut di air. Pada berbagai situasi, proses pewarnaan menggunakan mordant untuk meningkatkan kemampuan menempel bahan pewarna. Salah satu penggunaan bahan pewarna adalah sebagai bahan pewarna makanan 
TABLE II. CONTOH Sifat Pigmen Alami

\begin{tabular}{|c|c|c|c|c|}
\hline $\begin{array}{c}\text { Jenis } \\
\text { pigmen }\end{array}$ & Warna & Sumber & $\begin{array}{c}\text { Dapat } \\
\text { larut } \\
\text { dalam }\end{array}$ & Kestabilan \\
\hline Antosianin & $\begin{array}{c}\text { Jingga,merah, } \\
\text { biru }\end{array}$ & Tanaman & Air & $\begin{array}{c}\text { Peka terhadap } \\
\text { perubahan } \mathrm{pH}, \\
\text { panas }\end{array}$ \\
\hline Flavonoid & $\begin{array}{c}\text { Tak } \\
\text { berwarna, } \\
\text { kuning }\end{array}$ & $\begin{array}{l}\text { Umumnya } \\
\text { Tanaman }\end{array}$ & Air & Tahan panas \\
\hline $\begin{array}{c}\text { leukoantosi } \\
\operatorname{nin}\end{array}$ & Tak berwarna & tanaman & Air & Tahan panas \\
\hline Tanin & $\begin{array}{c}\text { Tak berwarna, } \\
\text { kuning }\end{array}$ & Tanaman & Air & Tahan panas \\
\hline Betanin & Kuning merah & Tanaman & Air & $\begin{array}{c}\text { Peka terhadap } \\
\text { panas }\end{array}$ \\
\hline Kuinon & $\begin{array}{c}\text { Kuning } \\
\text { sampai hitam }\end{array}$ & $\begin{array}{c}\text { Tanaman, } \\
\text { alga,bacteri }\end{array}$ & Air & Tahan panas \\
\hline Xanton & Kuning & Tanaman & Air & Tahan panas \\
\hline Karatonoid & $\begin{array}{l}\text { Tak berwarna, } \\
\text { kuning, merah }\end{array}$ & Tanaman & Lemak & Tahan panas \\
\hline Klorofil & Hijau,coklat & Tanaman & $\begin{array}{c}\text { Lemak, } \\
\text { air }\end{array}$ & $\begin{array}{c}\text { Peka terhadap } \\
\text { panas }\end{array}$ \\
\hline
\end{tabular}

a. Sumber: [6]

Pewarna makanan digolongkan sebagai aditif makanan sehingga diproduksi dengan standar tinggi tidak seperti pewarna untuk industri.Pewarna makanan dapat berupa pewarna jenis direct, mordant dan vat, dan penggunaannya secara ketat dikontrol hukum. Pewarna makanan dapat juga berasal dari alam. Zat warna/pewarna makanan secara umum dapat dibagi menjadi tiga golongan, yaitu :

- zat warna alami

- zat warna yang identik dengan zat warna alami

- zat warna sintetis.

\section{A. Zat Warna Alami}

Zat warna alami adalah zat warna yang diperoleh dari tumbuhan,hewan, atau dari sumber-sumber mineral. Zat warna ini telah sejak dahulu digunakan untuk pewarna makanan dan sampai sekarang umumnya penggunaannya dianggap lebih aman daripada zat warna sintetis. Jenis zat warna alami yang sering digunakan untuk pewarna makanan antara lain ialah : karotenoid, antosianin, kurkum, biksin, karamel, titanium oksida, cochineal, karmin dan asam karminat. Beberapa contoh zat pewarna alami yang biasa digunakan untuk mewarnai makanan adalah:

- KAROTEN, menghasilkan warna jingga sampai merah. Biasanya digunakan untuk mewarnai produk-produk minyak dan lemak seperti minyak goreng dan margarin. Dapat diperoleh dari wortel, papaya dan sebagainya.

- BIKSIN, memberikan warna kuning seperti mentega. Biksin diperoleh dari biji pohon Bixa orellana yang terdapat di daerah tropis dan sering digunakan untuk mewarnai mentega, margarin, minyak jagung dan salad dressing.
- KARAMEL, berwarna coklat gelap dan merupakan hasil dari hidrolisis (pemecahan) karbohidrat, gula pasir, laktosa dan sirup malt. Karamel terdiri dari 3 jenis, yaitu karamel tahan.

- asam yang sering digunakan untuk minuman berkarbonat, karamel cair untuk roti dan biskuit,serta caramel kering. Gula kelapa yang selain berfungsi sebagai pemanis, juga memberikan warna merah kecoklatan pada minuman es kelapa ataupun es cendol

- KLOROFIL, menghasilkan warna hijau, diperoleh dari daun. Banyak digunakan untuk makanan. Saat ini bahkan mulai digunakan pada berbagai produk kesehatan. Pigmen klorofil banyak terdapat pada dedaunan (misal daun suji, pandan, katuk dan sebaginya). Daun suji dan daun pandan, daun katuk sebagai penghasil warna hijau untuk berbagai jenis kue jajanan pasar. Selain menghasilkan warna hijau yang cantik, juga memiliki harum yang khas.

- ANTOSIANIN, penyebab warna merah, oranye, ungu dan biru banyak terdapat pada bunga dan buah-buahan seperti bunga mawar, pacar air, kembang sepatu, bunga tasbih/kana, krisan, pelargonium, aster cina, dan buah apel,chery, anggur, strawberi, juga terdapat pada buah manggis dan umbi ubi jalar. Bunga telang, menghasilkan warna biru keunguan. Bunga belimbing sayur menghasilkan warna merah. Penggunaan zat pewarna alami, misalnya pigmen antosianin masih terbatas pada beberapa produk makanan, seperti produk minuman (sari buah, juice dan susu).Kurkumin,berasal dari kunyit sebagai salah satu bumbu dapur sekaligus pemberi warna kuning pada masakan yang kita buat.

\section{B. Zat Warna yang Identik dengan Zat Warna Alami}

Zat warna ini masih satu golongan dengan kelompok zat warna alami, hanya zat warna ini dihasilkan dengan cara sintesis kimia, bukan dengan cara ekstraksi atau isolasi. Jadi pewarna identik alami adalah pigmen pigmen yang dibuat secara sintetis yang struktur kimianya identik dengan pewarna pewarna alami. Yang termasuk golongan ini adalah karotenoid murni antara lain canthaxanthin (merah), apo-karoten (merahoranye), beta karoten (oranye-kuning). Semua pewarnapewarna ini memiliki batas-batas konsentrasi maksimum penggunaan, terkecuali beta-karoten yang boleh digunakan dalam jumlah tidak terbatas

\section{Zat Warna Sintetis Berdasarkan rumus kimianya}

Zat warna sintetis dalam makanan menurut "Joint FAO/WHO Expert Committee on Food Additives" (JECFA) dapat digolongkan dalam beberapa kelas, yaitu azo,triarilmetana, quinolin,xantendanindigoid. Kelas azo merupakan zat warna sintetis yang paling banyak jenisnya danmencakup warna kuning, oranye, merah, ungu, dan coklat, setelah itu kelas triarilmetana yang mencakup warna biru dan hijau.

Analisa Zat Warna Makanan Analisa zat warna makanan dapat dilakukan dengan metode kromatografi. Kromatografi adalah suatu nama yang diberikan untuk teknik pemisahan 
tertentu. Cara yang asli telah diketengahkan pada tahun 1903 oleh TSWETT, ia telah menggunakan untuk pemisahan senyawa-senyawa yang berwarna, dan nama kromatografi diambilkan dari senyawa yang berwarna. HPLC adalah salah satu inovasi dari kromatografi cairan. HPLC (Kromatografi cairan Penampilan Tinggi) adalah kromatografi cairan modern, memiliki daya pemisahan yang tinggi dan kecepatan analisis dicapai dengan pertolongan fase-fase stasioner yang secara teknologis inovatif, yang memungkinkan fase gerak berkecepatan tinggi.Dari sumber yang kami peroleh, telah dilakukan analisis beberapa zat warna sintetik dari beberapa makanan dan minuman yang beredar di kota Bandung secara kromatografi cair kinerja tinggi dengan sistem fase balik, kolom C-18, fase gerak metanol:air (30:70) pada panjang gelombang $254 \mathrm{~nm}$. Zat warna tersebut diisolasi mula-mula dengan isoamilalkohol pada $\mathrm{pH} 1$, kemudian berturut-turut dengan n-heksan dan air. Hasil menunjukkan bahwa kadar kuning kuinolin dalam limun dan jeli berturut-turut adalah 9,46 mg/1 dan 1,07 mg/kg; jingga $\mathrm{G}$ dalam limun, jeli, dan saus berturut-turut adalah $3,39 \mathrm{mg} / 1,3,78 \mathrm{mg} / \mathrm{kg}$, dan 4 $\mathrm{mg} / \mathrm{kg}$; karmoisin dalam limun $3,43 \mathrm{mg} / \mathrm{l}$; dan auramin dalam adonan tepung pisang goreng $3,81 \mathrm{mg} / \mathrm{kg}[7,8]$

\section{BAHAN DAN METODE}

\section{A. Bahan}

Bahan baku yang digunakan : labu kuning matang yang teksturnya tidak terlalu lunak yang diperoleh dari pedagang buah. Bahan pembantu yang digunakan : pelarut aseton Teknis , etil asetat $100 \%$.

\section{B. Alat}

Alat yang digunakan : pisau, nyiru, slicer,loyang,blender, plastik, oven, Ayakan mesh 60, gelas piala, corong, kertas saring, timbangan analitik, water bath, uv/vis spectrometer, $\mathrm{pH}$ meter, alat pengaduk, penyaring vakum ,pipet tetes, aluminium foil.

\section{Metodologi}

Penelitian ini dilakukan dengan 2 tahap yaitu

1. Penelitian pendahuluan :

a. Analisa proksimat terhadap buah labu kuning :

- kadar protein $(\%)$ metode kjeldahl

- kadar lemak (\%) metode ekstraksi langsung

- karbohidrat/pati (\%) metode luff scroll

- kadar serat ( \% ) metode gravimetric

- kadar air (\%) metode gravimetri

b. Pembuatan tepung labu kuning

- Labu kuning dikupas, di blansir 5-10 menit

- Kemudian di iris tipis-tipis dan dikeringkan pada suhu $50-60^{\circ} \mathrm{C}$
- Chip labu kuning di blender kemudian di uji rendemen,protein,lemak,karbohidrat,serat dan kadar air

c. pembuatan ekstrak karotenoid dari labu kuning

Tepung labu kuning di ekstrak kemudian di saring, filtrat di uapkan dan didapatkan ekstrak warna.

2. Penelitian lanjutan : Pengamatan zat warna hasil isolasi

\section{HASIL DAN PEMBAHASAN}

Labu yang digunakan adalah Labu jenis Kuning.

TABLE III. HASIL ANALISA RATA RATA LABU KUNING PER $100 \mathrm{G}$

\begin{tabular}{|c|c|c|}
\hline Parameter Uji & Satuan & Hasil uji \\
\hline Kadar air & $\%$ & 92,08 \\
\hline Kadar abu & $\%$ & 0,88 \\
\hline Kadar protein & $\%$ & 1,61 \\
\hline Kadar lemak & $\%$ & 0,97 \\
\hline Karbohidrat & $\%$ & 2,38 \\
\hline Serat kasar & $\%$ & 0,88 \\
\hline
\end{tabular}

Hasil analisis bahan awal menunjukkan labu jenis kuning mempunyai kadar air yang tinggi 92,08 \% / $100 \mathrm{~g}$.

TABLE IV. HASIL ANALISA RATA RATA TEPUNG ABU PER $100 \mathrm{G}$

\begin{tabular}{|c|c|c|}
\hline Parameter Uji & Satuan & Hasil uji \\
\hline Kadar air & $\%$ & 10,31 \\
\hline Kadar abu & $\%$ & 6,594 \\
\hline Kadar protein & $\%$ & 6,59 \\
\hline Kadar lemak & $\%$ & 8,73 \\
\hline Karbohidrat & $\%$ & 35,82 \\
\hline Serat kasar & $\%$ & 0,48 \\
\hline
\end{tabular}

Berdasarkan pengaruh ratio bb : pelarut dan lama ekstraksi dengan pelarut aseton maka dapat dihitung rendemen dan intensitas warna seperti tertera pada tabel V di bawah ini. 
TABLE V. HASIL PENGAMATAN RERATA RENDEMEN, PH, INTENSITAS WARNA, EKSTRAK KAROTENOID AKIBAT PENGARUH RATIO B.B : PELARUT DAN LAMA EKSTRAKSI DENGAN PELARUT ASETON

\begin{tabular}{|c|c|c|c|c|c|c|c|c|c|c|}
\hline perbandingan & kode & berat & waktu(menit) & ph & berat kosong(g) & berat sth ekstraksi (g) & selisih(g) & \%Rendemen & $\lambda(\mathrm{nm})$ & absorban \\
\hline 1:05 & 1 & 1.0047 & 5 & 6 & 63.3076 & 63.3236 & 0.016 & 1.592515179 & 405 & 0.3227 \\
\hline serbuk: aseton) & 2 & 1.0078 & 15 & 6.03 & 62.6056 & 62.6196 & 0.014 & 1.389164517 & 395 & 0.4025 \\
\hline & 3 & 1.03 & 25 & 6.15 & 47.4051 & 47.4169 & 0.0118 & 1.145631068 & 395 & 0.4935 \\
\hline 1:10 & 4 & 1.0212 & 5 & 6.15 & 61.5482 & 61.5734 & 0.0252 & 2.467685076 & 395 & 0.3177 \\
\hline & 5 & 1.0438 & 15 & 6.24 & 62.9901 & 63.0158 & 0.0257 & 2.462157501 & 395 & 0.3357 \\
\hline & 6 & 1.0037 & 25 & 6.28 & 39.916 & 39.9399 & 0.0239 & 2.381189598 & 395 & 0.394 \\
\hline 1:15 & 7 & 1.0744 & 5 & 6.42 & 46.9967 & 47.0354 & 0.0387 & 3.602010424 & 395 & 0.2732 \\
\hline & 8 & 1.005 & 15 & 6.38 & 58.9547 & 58.9867 & 0.032 & 3.184079602 & 395 & 0.3237 \\
\hline & 9 & 1.0443 & 25 & 6.26 & 40.2386 & 40.2749 & 0.0363 & 3.47601264 & 395 & 0.2864 \\
\hline 1:20 & 10 & 1.0145 & 5 & 6.61 & 42.172 & 42.2454 & 0.0734 & 7.235091178 & 395 & 0.1668 \\
\hline & 11 & 1.0546 & 15 & 6.32 & 40.6685 & 40.7486 & 0.0801 & 7.595296795 & 395 & 0.1362 \\
\hline & 12 & 1.0075 & 25 & 6.24 & 42.3014 & 42.3553 & 0.0539 & 5.349875931 & 395 & 0.1955 \\
\hline $1: 25$ & 13 & 1.0212 & 5 & 6.47 & 41.8823 & 41.9453 & 0.063 & 6.169212691 & 395 & 0.1051 \\
\hline & 14 & 1.0451 & 15 & 6.38 & 42.3928 & 42.452 & 0.0592 & 5.66452971 & 395 & 0.1376 \\
\hline & 15 & 1.0042 & 25 & 6.52 & 42.8174 & 42.8646 & 0.0472 & 4.700258913 & 395 & 0.2164 \\
\hline 1:30 & 16 & 1.0028 & 5 & 6.58 & 40.6433 & 40.6862 & 0.0429 & 4.27802154 & 395 & 0.2379 \\
\hline & 17 & 1.0737 & 15 & 6.38 & 37.5752 & 37.616 & 0.0408 & 3.799944118 & 395 & 0.2961 \\
\hline & 18 & 1.0248 & 25 & 6.35 & 42.7383 & 42.7808 & 0.0425 & 4.147150664 & 395 & 0.2908 \\
\hline
\end{tabular}

TABLE VI. THASIL PENGAMATAN RERATA RENDEMEN, PH, INTENSITAS WARNA, EKSTRAK KAROTENOID AKIBAT PENGARUH RATIO B.B : PELARUT DAN LAMA EKSTRAKSI DENGAN PELARUT ETIL ASETAT

\begin{tabular}{|c|c|c|c|c|c|c|c|c|c|}
\hline perbandingan & berat & waktu(menit) & $\mathrm{ph}$ & berat kosong(g) & berat sth ekstraksi (g) & selisih(g) & Rendeme & $\lambda(\mathrm{nm})$ & absorban \\
\hline 1:05 & 1.0001 & 5 & 5.22 & 58.9533 & 58.9609 & 0.0076 & 0.75992 & 421.1 & 0.0198 \\
\hline \multirow[t]{2}{*}{ ( serbuk : etil asetat) } & 1.0256 & 15 & 4.19 & 50.1372 & 50.1519 & 0.0147 & 1.43331 & 421.1 & 0.0536 \\
\hline & 1.0007 & 25 & 4.02 & 63.308 & 63.3233 & 0.0153 & 1.52893 & 421.1 & 0.8184 \\
\hline \multirow[t]{3}{*}{$1: 10$} & 1.0059 & 5 & 4.74 & 61.548 & 61.5535 & 0.0055 & 0.54677 & 421.1 & 0.074 \\
\hline & 1.0129 & 15 & 4.36 & 62.606 & 62.6173 & 0.0113 & 1.11561 & 421.1 & 0.1442 \\
\hline & 1.009 & 25 & 4.11 & 66.6853 & 66.7014 & 0.0161 & 1.59564 & 421.1 & 0.0646 \\
\hline \multirow[t]{3}{*}{$1: 15$} & 1.0109 & 5 & 4.48 & 62.9895 & 62.9965 & 0.007 & 0.69245 & 421.1 & 0.1753 \\
\hline & 1.0417 & 15 & 4.29 & 57.9167 & 57.93 & 0.0133 & 1.27676 & 421.1 & 0.0921 \\
\hline & 1.028 & 25 & 3.93 & 30.0724 & 30.0892 & 0.0168 & 1.63424 & 421.1 & 0.1855 \\
\hline \multirow[t]{3}{*}{$1: 20$} & 1.0007 & 5 & 5.38 & 63.3045 & 63.324 & 0.0195 & 1.94864 & 400 & 0.54 \\
\hline & 1.0341 & 15 & 4.57 & 62.5987 & 62.6205 & 0.0218 & 2.10811 & 400 & 0.5322 \\
\hline & 1.0114 & 25 & 4.22 & 47.4014 & 47.4252 & 0.0238 & 2.35317 & 420 & 0.5059 \\
\hline \multirow[t]{3}{*}{$1: 25$} & 1.0397 & 5 & 4.2 & 61.5426 & 61.5638 & 0.0212 & 2.03905 & 420 & 0.576 \\
\hline & 1.043 & 15 & 4.14 & 62.9862 & 63.0067 & 0.0205 & 1.96548 & 420 & 0.5346 \\
\hline & 1.0422 & 25 & 4.08 & 46.2604 & 46.2817 & 0.0213 & 2.04375 & 420 & 0.5402 \\
\hline \multirow[t]{3}{*}{$1: 30$} & 1.0165 & 5 & 3.94 & 46.9956 & 47.0131 & 0.0175 & 1.72159 & 420 & 0.5996 \\
\hline & 1.0223 & 15 & 3.66 & 58.953 & 58.9717 & 0.0187 & 1.82921 & 420 & 0.62 \\
\hline & 1.0955 & 25 & 3.54 & 30.0711 & 30.089 & 0.0179 & 1.63396 & 420 & 0.7296 \\
\hline
\end{tabular}




\section{JURNAL TEKNOLOGI PROSES DAN INOVASI INDUSTRI, VOL. 4, NO. 2, NOVEMBER 2019}

Hasil pengamatan intensitas warna dilakukan pada suhu $30^{\circ} \mathrm{C}$, dengan lama pengamatan 1 jam dan 2 jam, hasil pengamatan terhadap intensitas warna dari ekstrak karotenoid terjadi penurunan absorbansi maksimun pada panjang gelom bang $409 \lambda \mathrm{m}$ ( gb 3 ), absorbansi maksimumnya 0,369, pada pengamatan 1 jam, setelah 2 jam, absorbansi maksimumnya 0,335 . kondisi penyimpanan sangat ber pengaruh pada stabilitas karotenoid.

Pengaruh lama pemanasan

- $10 \mathrm{ml}$ larutan pigmen $0,1 \%$ masukkan dalam tabung reaksi, panaskan pada suhu $100^{\circ} \mathrm{C}$, selama 1 jam, volume dikembalikan ke volume awal.Amati absorbansinya pada panjang gelombang $(\lambda)=400-500 \mathrm{~nm}$

- $10 \mathrm{ml}$ larutan pigmen $0,1 \%$ masukkan dalam tabung reaksi, panaskan pada suhu $100^{\circ} \mathrm{C}$, selama 2 jam, volume dikembalikan ke volume awal. Menguji absorbansinya pada panjang gelombang $(\lambda)=400-500 \mathrm{~nm}$
Pengaruh suhu

- $10 \mathrm{ml}$ larutan pigmen $0,1 \%$ masukkan dalam tabung reaksi, tempatkan pada suhu $30^{\circ} \mathrm{C}$, selama 1 jam, volume dikembalikan ke volume awal.Amati absorbansinya pada panjang gelombang $(\lambda)=400-500 \mathrm{~nm}$

- $10 \mathrm{ml}$ larutan pigmen $0,1 \%$ masukkan dalam tabung reaksi, tempatkan pada suhu $30^{\circ} \mathrm{C}$, selama 2 jam, volume dikembalikan ke volume awal.Amati absorbansinya pada panjang gelombang $(\lambda)=400-500 \mathrm{~nm}$

Pengaruh kondisi penyimpanan

- $100 \mathrm{ml}$ larutan pigmen 0,1 disimpan pada suhu dingin $\pm 15^{\circ}$ $\mathrm{C}$ (kulkas) selama 5 hari. Kemudian diukur absorbansinya pada panjang gelombang $(\lambda)=400-500 \mathrm{~nm}$

TABLE VII. HASIL PENGAMATAN INTENSITAS WARNA PADA PENYIMPANAN PADA SUHU $30^{\circ} \mathrm{C}$ SELAMA $2 \mathrm{JAM}$

\begin{tabular}{|c|c|c|c|c|c|c|c|c|c|c|c|}
\hline \multirow{3}{*}{$\lambda$} & \multicolumn{2}{|c|}{ AWAL } & \multirow{3}{*}{ rata-rata } & \multirow{3}{*}{$\lambda$} & \multicolumn{2}{|c|}{$1 \mathrm{JAM}$} & \multirow{3}{*}{ rata-rata } & \multirow{3}{*}{$\lambda$} & \multicolumn{2}{|c|}{2 JAM } & \multirow{3}{*}{ rata-rata } \\
\hline & \multirow{2}{*}{\begin{tabular}{|l|} 
A1C1 \\
Abs \\
\end{tabular}} & \multirow{2}{*}{\begin{tabular}{|l|} 
A1C2 \\
Abs \\
\end{tabular}} & & & \multirow{2}{*}{\begin{tabular}{|l|} 
A1C1 \\
Abs \\
\end{tabular}} & \multirow{2}{*}{\begin{tabular}{|l} 
A1C2 \\
Abs
\end{tabular}} & & & \multirow{2}{*}{\begin{tabular}{|l|} 
A1C1 \\
Abs \\
\end{tabular}} & \multirow{2}{*}{\begin{tabular}{|l|} 
A1C2 \\
Abs \\
\end{tabular}} & \\
\hline & & & & & & & & & & & \\
\hline 433 & 0.4258 & 0.3609 & 0.39335 & 433 & 0.335 & 0.325 & 0.33 & 433 & 0.2834 & 0.2303 & 0.25685 \\
\hline 425 & 0.4515 & 0.3856 & 0.41855 & 425 & 0.3563 & 0.346 & 0.35115 & 425 & 0.3204 & 0.2618 & 0.2911 \\
\hline 420 & 0.4575 & 0.3981 & 0.4278 & 420 & 0.3599 & 0.39 & 0.37495 & 420 & 0.3393 & 0.2786 & 0.30895 \\
\hline 417 & 0.4669 & 0.4128 & 0.43985 & 417 & 0.3678 & 0.3544 & 0.3611 & 417 & 0.3499 & 0.2878 & 0.31885 \\
\hline 409 & 0.4761 & 0.4128 & 0.44445 & 409 & 0.3747 & 0.364 & 0.36935 & 409 & 0.3677 & 0.303 & 0.33535 \\
\hline 401 & 0.4675 & 0.4155 & 0.4415 & 401 & 0.3614 & 0.3605 & 0.36095 & 401 & 0.3859 & 0.318 & 0.35195 \\
\hline 393 & 0.4933 & 0.441 & 0.46715 & 393 & 0.3789 & 0.3776 & 0.37825 & 393 & 0.3766 & 0.3161 & 0.34635 \\
\hline 385 & 0.5204 & 0.4706 & 0.4955 & 385 & 0.4013 & 0.4013 & 0.4013 & 385 & 0.3799 & 0.322 & 0.35095 \\
\hline
\end{tabular}

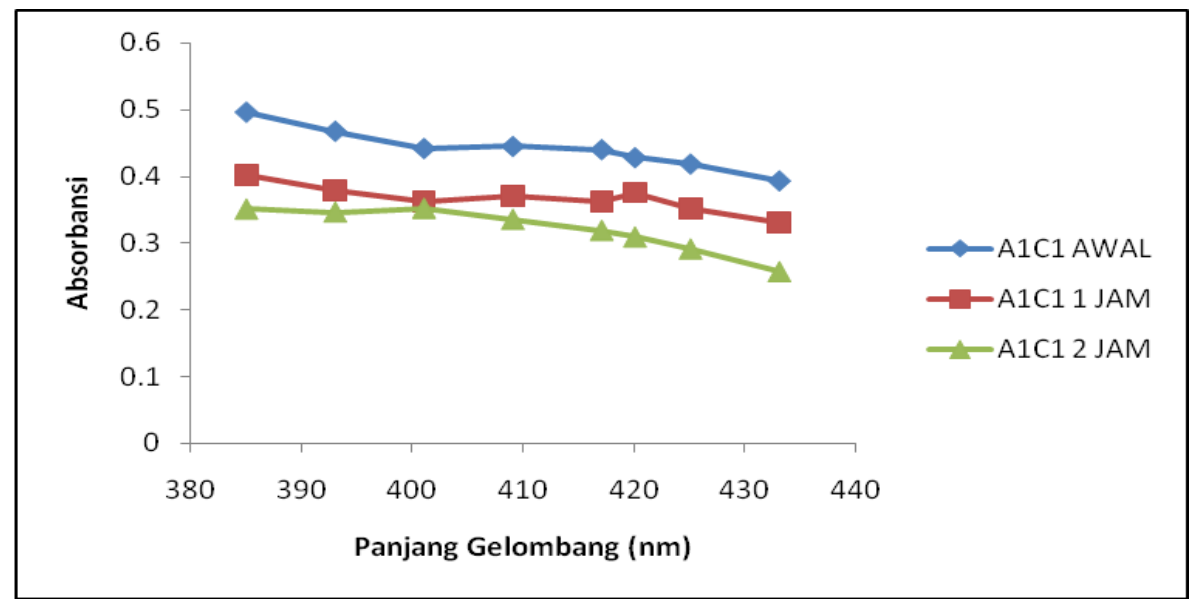

Gambar 1.Grafik spektrum absorbansi ekstrak pigmen terhadap pegaruh suhu $30^{\circ} \mathrm{C}$ selama 2 jam.

Pengaruh lama pemanasan dilakukan pada suhu $100^{\circ} \mathrm{C}$, dengan lama pemana san 1 jam dan 2 jam, hasil pengamatan terhadap intensitas warna dari ekstrak karotenoid terjadi penurunan absorbansi maksimun pada panjang gelombang $417 \lambda \mathrm{m}$ ( gb 4 ). Pada pemanasan 1 jam intensitas warna memiliki absorbansi maksimum 0,355 , sedang pemanasan 2 jam absorbansi maksimumnya 0,283, Penurunan absorbansi disebabkan kerusakan dan perubahan struktur pigmen. 
TABLE VIII. HASIL PENGAMATAN INTENSITAS WARNA PADA PENYIMPANAN PADA SUHU $100^{\circ} \mathrm{C}$ SELAMA 2 JAM

\begin{tabular}{|r|r|r|r|}
\hline \multirow{2}{*}{$\lambda$} & \multicolumn{2}{|c|}{ AWAL } & \multirow{2}{*}{ RATA-RATA } \\
\cline { 2 - 3 } & A1B1 & A1B2 & \\
\cline { 2 - 3 } & Abs & Abs & \\
\hline 433 & 0.4459 & 0.3912 & 0.41855 \\
\hline 425 & 0.4482 & 0.403 & 0.4256 \\
\hline 420 & 0.4403 & 0.4012 & 0.42075 \\
\hline 417 & 0.4428 & 0.4068 & 0.4248 \\
\hline 409 & 0.4387 & 0.4111 & 0.4249 \\
\hline 401 & 0.4131 & 0.3939 & 0.4035 \\
\hline
\end{tabular}

\begin{tabular}{|r|r|r|r|}
\hline \multirow{3}{*}{$\lambda$} & 1 JAM & & \multirow{2}{*}{} \\
\cline { 2 - 3 } & A1B1 & A1B2 & RATA-RATA \\
\cline { 2 - 3 } & Abs & Abs & \\
\hline 433 & 0.3681 & 0.319 & 0.34355 \\
\hline 425 & 0.3743 & 0.3351 & 0.3547 \\
\hline 420 & 0.3691 & 0.335 & 0.35205 \\
\hline 417 & 0.3714 & 0.3397 & 0.35555 \\
\hline 409 & 0.3732 & 0.3468 & 0.36 \\
\hline 401 & 0.358 & 0.3399 & 0.34895 \\
\hline
\end{tabular}

\begin{tabular}{|r|r|r|r|}
\hline \multirow{2}{*}{$\lambda$} & 2 JAM & & \multirow{2}{*}{ RATA-RATA } \\
\cline { 2 - 3 } & A1B1 & A1B2 & RAT \\
\cline { 2 - 3 } & Abs & Abs & \\
\hline 433 & 0.281 & 0.1891 & 0.23505 \\
\hline 425 & 0.3085 & 0.2147 & 0.2616 \\
\hline 420 & 0.3224 & 0.2293 & 0.27585 \\
\hline 417 & 0.3295 & 0.2373 & 0.2834 \\
\hline 409 & 0.3378 & 0.2493 & 0.29355 \\
\hline 401 & 0.3454 & 0.2595 & 0.30245 \\
\hline
\end{tabular}

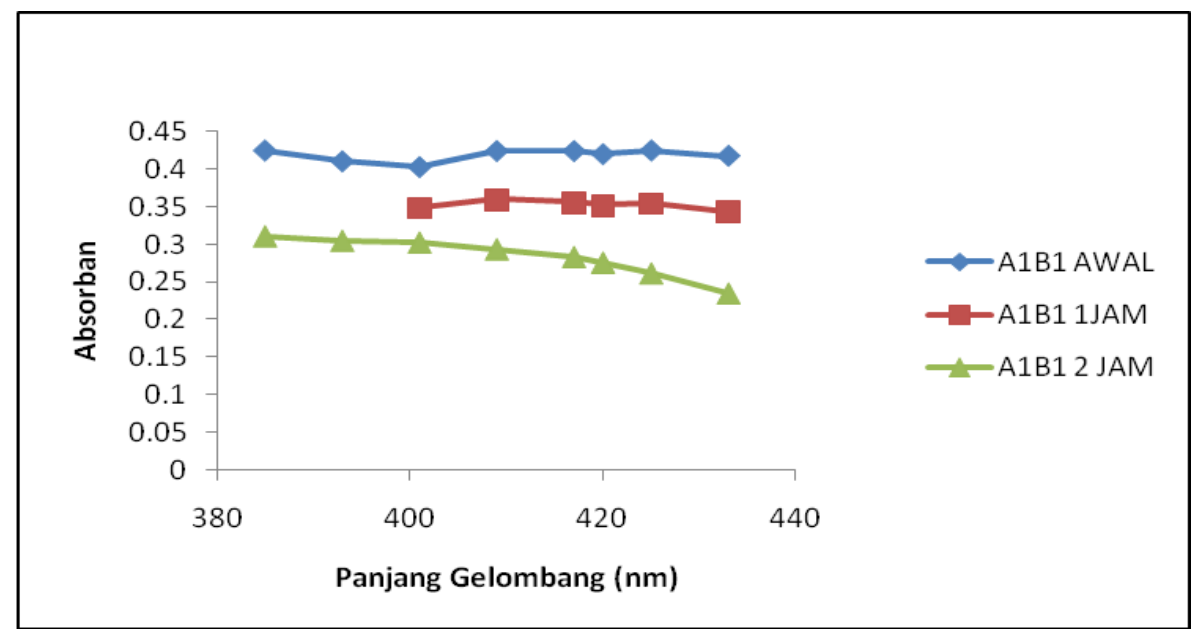

Gambar 2. Grafik spektrum absorbansi ekstrak pigmen terhadap pegaruh suhu $100{ }^{\circ} \mathrm{C}$ selama 2 jam

Hasil pengamatan intensitas warna dilakukan pada penyimpanan pada lemari es selama 5 hari, hasil pengamatan terhadap intensitas warna dari ekstrak karotenoid terjadi penurunan absorbansi maksimun pada panjang gelom bang $401 \lambda \mathrm{m}$ ( gb 5 ), absorbansi maksimumnya 0,364, pada pengamatan selama 5 hari, absorbansi maksimumnya mengalami penurunan menjadi 0,1904. Kondisi penyimpanan sangat berpengaruh pada stabilitas karotenoid.

TABLE IX. HASIL PENGAMATAN INTENSITAS WARNA PADA PENYIMPANAN PADA LEMARI ES SELAMA 5 HARI

\begin{tabular}{|c|c|c|c|c|c|c|c|c|c|c|c|}
\hline \multicolumn{2}{|c|}{ AWAL } & \multicolumn{2}{|c|}{ HARI1 } & \multicolumn{2}{|c|}{ HARI2 } & \multicolumn{2}{|c|}{ HARI3 } & \multicolumn{2}{|c|}{ HARI4 } & \multicolumn{2}{|c|}{ HARI5 } \\
\hline \multicolumn{2}{|c|}{ A1D1 } & \multicolumn{2}{|c|}{ A1D1 } & \multicolumn{2}{|c|}{ A1D1 } & \multicolumn{2}{|c|}{ A1D1 } & \multicolumn{2}{|c|}{ A1D1 } & \multicolumn{2}{|c|}{ A1D1 } \\
\hline$\lambda$ & Abs & $\lambda$ & Abs & $\lambda$ & Abs & $\lambda$ & Abs & $\lambda$ & Abs & $\lambda$ & Abs \\
\hline 433 & 0.3649 & 433 & 0.2835 & 433 & 0.2162 & 433 & 0.1746 & 433 & 0.092 & 433 & 0.0997 \\
\hline 425 & 0.3724 & 425 & 0.3077 & 425 & 0.2406 & 425 & 0.1928 & 425 & 0.1158 & 425 & 0.1247 \\
\hline 420 & 0.3698 & 420 & 0.3164 & 420 & 0.2448 & 420 & 0.2031 & 420 & 0.1006 & 420 & 0.1364 \\
\hline 417 & 0.3728 & 417 & 0.3187 & 417 & 0.2488 & 417 & 0.2122 & 417 & 0.124 & 417 & 0.1426 \\
\hline 409 & 0.376 & 409 & 0.3204 & 409 & 0.2634 & 409 & 0.2364 & 409 & 0.1438 & 409 & 0.1654 \\
\hline 401 & 0.3642 & 401 & 0.3268 & 401 & 0.2889 & 401 & 0.2466 & 401 & 0.1609 & 401 & 0.1904 \\
\hline 393 & 0.3767 & 393 & 0.3151 & 393 & 0.2996 & 393 & 0.2572 & 393 & 0.181 & 393 & 0.2138 \\
\hline 385 & 0.3944 & 385 & 0.3112 & 385 & 0.3038 & 385 & 0.2632 & 385 & 0.2069 & 385 & 0.2264 \\
\hline
\end{tabular}




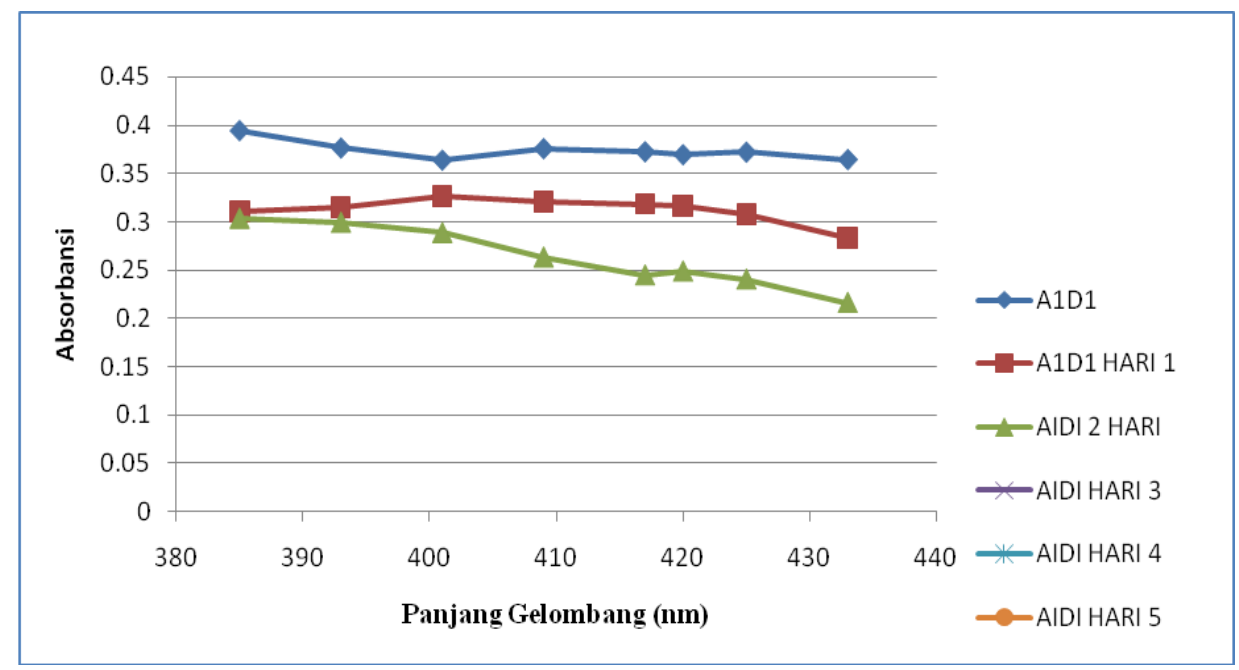

Gambar 3. Grafik spektrum absorbansi ekstrak pigmen terhadap pegaruh penyimpanan pada lemari es 5 hari

TABLE X. HASIL PENGAMATAN WARNA SIRUP SECARA VISUAL

\begin{tabular}{|c|c|c|}
\hline Minggu & $\begin{array}{c}\text { Pengamatan warna sirup } \\
\text { pada suhu kamar }\end{array}$ & $\begin{array}{c}\text { Pengamatan warna } \\
\text { sirup pada lemari es }\end{array}$ \\
\hline 1 & Kuning cerah & Kuning cerah \\
\hline 2 & Kuning cerah & Kuning cerah \\
\hline 3 & Kuning cerah & Kuning cerah \\
\hline 4 & Kuning cerah & Kuning cerah \\
\hline 5 & Kuning cerah & Kuning cerah \\
\hline 6 & Kuning cerah & Kuning cerah \\
\hline 7 & Kuning cerah & Kuning cerah \\
\hline 8 & Kuning cerah & Kuning cerah \\
\hline
\end{tabular}

\section{KESIMPULAN DAN SARAN}

Dari penelitian Isolasi pewarna alami dari labu dan penerapanya untuk pewarna makanan dapat di simpulkan bahwa dari pengaruh suhu diperoleh hasil pengamatan intensitas warna yang dilakukan pada kondisi suhu $30^{\circ} \mathrm{C}$, sangat berpengaruh terhadap stabilitas karotenoid. Lamanya pemansan, dari hasil pengamatan intensitas warna yang dilakukan pada pemanasan pada suhu $100{ }^{\circ} \mathrm{C}$ sangat berpengaruh terhadap stabilitas karotenoid. Dari Pengaruh kondisi penyimpanan menunjukkan hasil pengamatan intensitas warna yang dilakukan pada lemari es selama 5 hari sangat berpengaruh terhadap stabilitas karotenoid. Sehingga diperoleh zat warna alami dari labu kuning yang dapat diaplikasikan untuk pewarna alami dari minuman diantaranya untuk sirup. Warna sirup yang dihasilkan memberikan warna kuning cerah pada pe ngamatan selama dua bulan pada suhu kamar maupun dalam lemari es.

\section{UCAPAN TERIMA KASIH}

Ucapkan terima kasih ditujukan kepada Baristand Industri Surabaya yang telah memberikan fasilitas sehingga penelitian ini dan ibu Dinarwi sebagai peneliti madya selaku pembimbing dan seluruh tim yang membantu penelitian ini.

\section{DAFTAR PUSTAKA}

[1] Persagi, “ Tabel Komposisi Pangan Indonesia ”, PT Elex Media Komputindo, Jakarta, 2009.

[2] Setyabudi MI "Potensi Tepung Wortel sebagai Sumber B-karoten dan Pewarna alami Pada Geplak, Fakulta Teknologi Pertanian Universitas Gajah Mada, Yogyakarta.

[3] Histifarina D, D Musaddad, dan E Murtiningsih “ Teknik Pengeringan dalam Oven untuk Irisan Wortel Kering Bermutu”, Balai Penelitian Tanaman Sayuran, Jurnal Hortikultuta 14(2) : 107-112 Silalahi Jansen ,Yogyakarta,2006.

[4] Legowo A, "Pengaruh Blanching terhadap Sifat Sensoris dan Kadar Provitamin Tepung Labu Kuning, Fakulta Teknologi Pertanian Universitas Gajah Mada, Yogyakarta, 2005.

[5] Gardjito," Labu Kuning sumber Karbohidrat kaya Vitamin A,Tridatu Visi Komunika,Yogyakarta, 2006.

[6] Winarno F.G,"Kimia Pangan dan Gizi, PT Gramedia Pustaka Utama, Jakarta,1997.

[7] http://apertiwi.blogspot.co.id/2009/05/pewarna-alami.html diakses 20 April 2015.

[8] https://guideprof.blogspot.co.id/2014/11/zat-pewarna-alami.html diakses 20 April 2015 